\title{
MOTIVASJON FOR SEPARATE NUMERUS OG DEFINITTPROJEKSJONAR I NORSK DP-STRUKTUR
}

\author{
TOR A. AFFARLI \\ Noregs teknisk-naturvitskaplege universitet
}

\section{SAMANDRAG}

I denne artikkelen vil eg legge fram og diskutere to ulike typar empiriske argument for å rekne med at DEF og NUM eksisterer som separate funksjonelle kjernar/projeksjonar i strukturen til DP i norsk. Det første argumentet har å gjere med språkblanding mellom norsk og engelsk, nærmare bestemt data der ein engelsk substantivstamme saman med det engelske pluralsuffikset -s blir blanda inn i norsk. Det andre argumentet har å gjere med interaksjonen mellom pre- og postnominale possessivar og bøyingsmorfologien knytt til substantivet i DPen. Analysane i begge tilfella viser klar evidens for at DEF og NUM må reknast som separate kjernar/projeksjonar. Artikkelen inneheld eksplisitte treanalysar av dei ulike fenomena som blir diskuterte.

\section{[1] INNLEIING}

Sidan DP-analysen for nominalfrasar vart introdusert mot slutten av 1980-talet (Hellan 1986, Abney 1987), har det etter kvart vorte eit viktig spørsmål kva projeksjonar som eksisterer i DP forutan D og N. I norsk reknar t.d. Julien (2005) med DEF(initt) og NUM(erus) (som Julien kallar respektive $\mathrm{n}$ og Num), motivert ved at norske substantiv kan ha både definitt- og numerusbøying. Julien reknar genus som inherent i substantivet.

Sjølv om norske substantiv kan ha både definitt- og numerusbøying, er det ikkje sjølvsagt at DEF og NUM eksisterer som separate funksjonelle projeksjonar. Ein kan lett tenkje seg at desse to eigenskapane eksisterer saman i éin funksjonell projeksjon. Det ville i så fall vere parallelt med måten ein i 1980-talets generative syntaks tenkte seg at agreement og tense eksisterte saman i ein I(NFL)-projeksjon i representasjonen av setningsstrukturen til engelsk. Men på same måte som Pollock (1989) argumenterte for at agreement og tense måtte eksistere som separate funksjonelle projeksjonar i setningstrukturen, har det vore rekna med at dei funksjonelle bøyingseigenskapane i DPen også eksisterer som separate funksjonelle projeksjonar. Motivasjonen for dette kan vere konseptuell-teoretisk fordi ein reknar med at to eigenskapar betyr to kjernar/projeksjonar. Men som Bobaljik \& Thrainsson (1998) argumenterte for, er ikkje alltid to 
kjernar/projeksjonar betre enn ein, sjølv ikkje når det er to eigenskapar det dreier seg om. Dei argumenterer med at det er eit empirisk spørsmål kor mange funksjonelle projeksjonar som eksisterer i ein representasjon, og at to (eller fleire) eigenskapar kan vere samla i ein og same projeksjon.

Hovudargumentet i Pollock (1989) for at agreement og tense måtte vere kjernar i separate funksjonelle projeksjonar i representasjonen av setningar i språk som engelsk og fransk, var nettopp empirisk. Når det gjeld DEF og NUM i norsk, synest det som om motivasjonen for to separate projeksjonar i hovudsak har vore konseptuell-teoretisk, medan det har vore uklart om det finst handfast empirisk motivasjon for dette, men sjå Julien (2005). I denne artikkelen skal eg gi to nye empiriske argument for at DEF og NUM må eksisterer som separate funksjonelle kjernar/projeksjonar i representasjonen av norske DPar.

Før eg går inn på dei to argumenta, skal eg i seksjon 2 seie litt om DP-struktur i norsk generelt, slik at vi har eit utgangspunkt. Deretter vil eg i seksjon 3 presentere det første argumentet for at DEF og NUM må eksistere som separate funksjonelle projeksjonar. Dette argumentet har med språkblanding å gjere. I seksjon 4 presenterer eg så det andre argumentet, som har med interaksjonen mellom DP-interne possessivar og substantivbøying å gjere. Seksjon 5 konkluderer artikkelen.

\section{[2] De-struktur}

Eg vil ta utgangspunkt i Juliens (2005) DP-struktur (gjengitt her frå Riksem 2018a, s. 58):

(1) a. dei gaml-e teikning-a-ne 


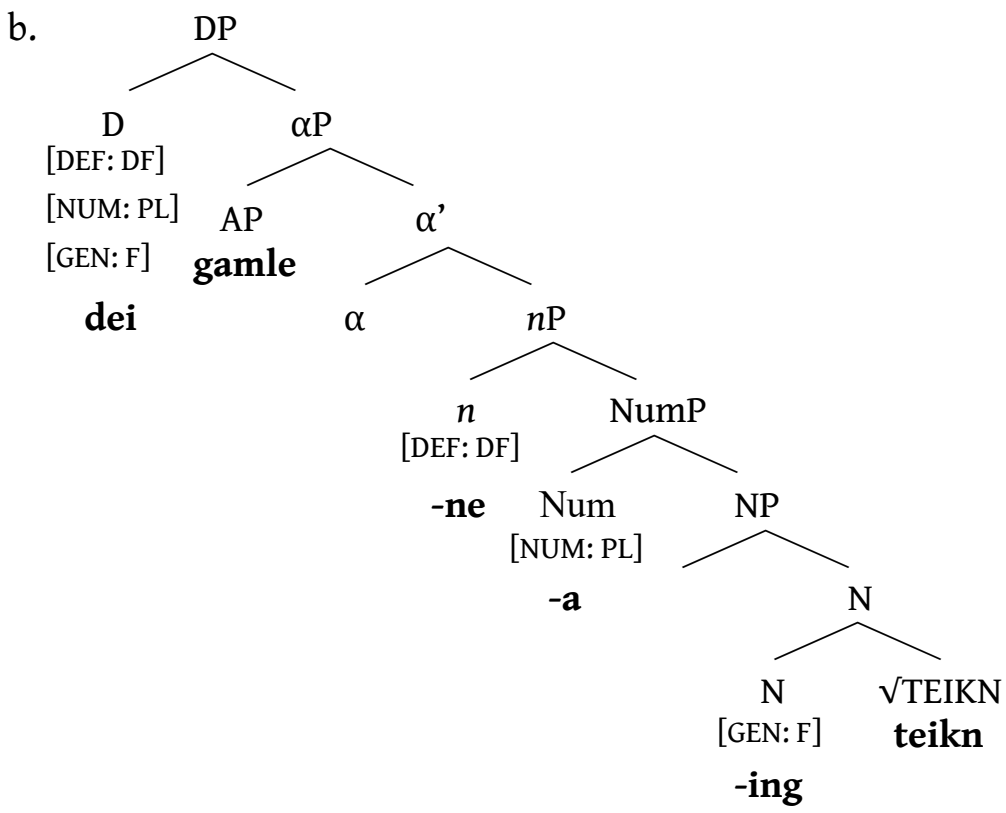

Eg kan ikkje gå inn på alle detaljane i denne strukturen, men det som er viktig for våre formål no, er at Julien reknar med to separate projeksjonar for DEF og NUM, som ho kallar respektivt ein n-projeksjon og Num-projeksjon. Vidare reknar Julien GEN(us) som inherent i substantivstammen, her vist som eit trekk i stammekjernen $\mathrm{N}$.

Det kan vere forvirrande at Julien brukar merkelappane «n» for DEF-projeksjonen og «N» for stammekjernen, sidan det som har vorte vanleg dei siste åra, er å bruke «n» for stammekjernen (dvs. kategorisatoren til rota, sjå t.d. Embick \& Noyer 2007, s. 296; Lohndal 2019, s. [18]). Eg vil derfor justere Juliens struktur i pakt med nyare konvensjonar og ta utgangspunkt i den strukturen som er gitt i t.d. Åfarli, Nygård \& Riksem (2020). Representasjonen nedanfor er ei skisse av denne justerte strukturen der det attributive adjektivet ikkje er tatt med. 
(2)

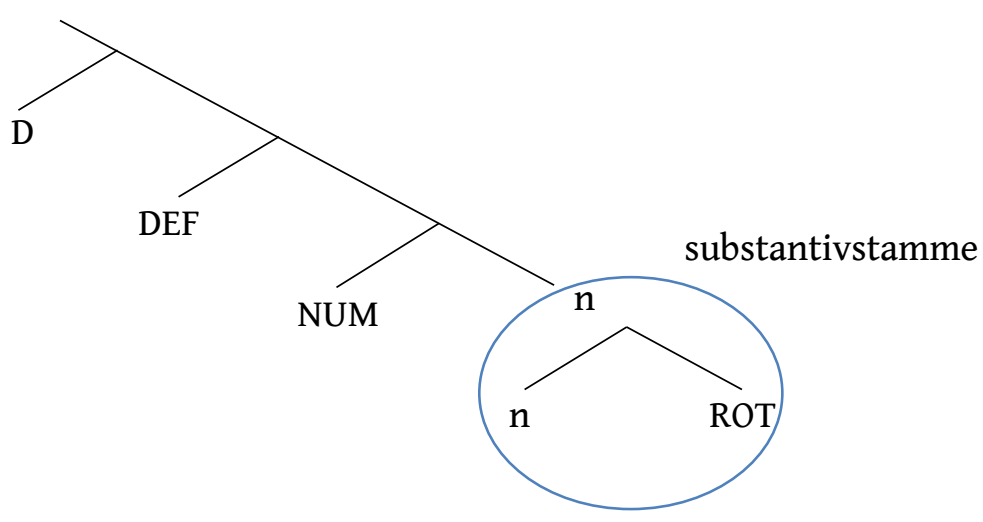

I den justerte representasjonen over er heller ikkje genus inkludert. Analysen av genus er generelt eit problematisk område, og Åfarli, Nygård \& Riksem (2020) er først og fremst eit arbeid som konsentrerer seg om dette. Men sidan genus ikkje er viktig for det som følgjer, har eg ikkje tatt med det. Eg viser likevel korleis Åfarli, Nygård \& Riksem (2020) tenkjer seg at genus er representert, nemleg som eit parasittisk trekk (u-gen) som potensielt finst på alle dei funksjonelle projeksjonane i DPen.

(3)

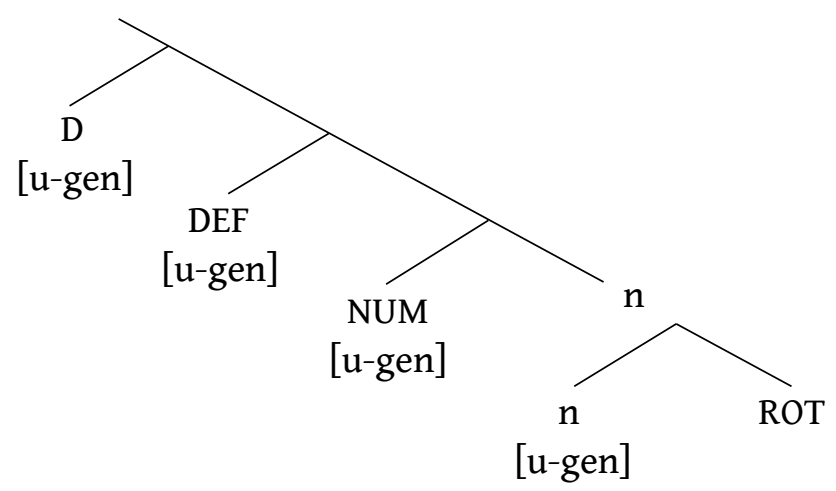

GEN er med andre ord ikkje kjerne i ein dedikert funksjonell projeksjon i dette systemet, ulikt det som gjeld for DEF og NUM, sjå elles op. cit. for ein grundig diskusjon av den strukturelle statusen til genus i norske DPar. Eg skal ikkje seie meir om genus/GEN og vender tilbake til hovudproblemet for denne artikkelen: Er DEF og NUM separate projeksjonar i norsk DP-struktur eller ikkje? Finst det nye empiriske argument som kan gi svar på dette spørsmålet?

Eit arbeid som reknar med at DEF og NUM (og også GEN) er samla i éin kjerne i éin projeksjon, er Riksem (2018b). Dette er eit arbeid som tar for seg 
språkblanding mellom norsk og engelsk i amerikanorsk. Riksems meir komprimerte analyse er diskutert i Riksem (2018b, s. 496-498); representasjonen nedanfor er gjengitt frå Riksem (2018a, s. 95).

(4)

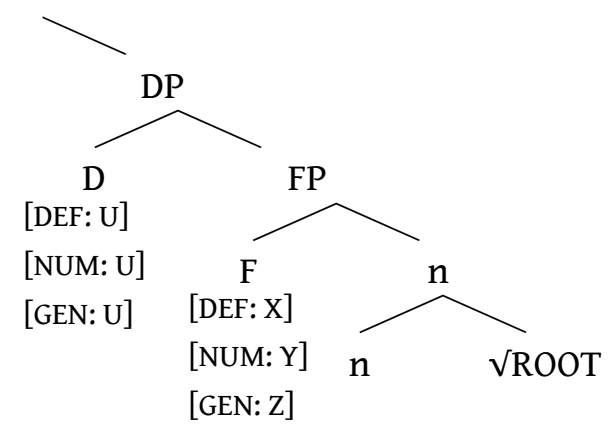

Det at Riksem brukar ein representasjon der DEF og NUM er samla i éin projeksjon, indikerer at den generelle motivasjonen for å rekne med to projeksjonar i slike tilfelle ikkje akkurat er overveldande, rett og slett fordi ho greier å gjere greie for sine data ved hjelp av berre éin kjerne/projeksjon. Vi skal likevel sjå at nettopp språkblandingsempiri gir oss grunn til å rekne med at DEF og NUM eksisterer som separate projeksjonar, og kimen til denne revurderinga er å finne i nettopp Riksem (2018b).

\section{[3] Motivasjon SOM HAR $̊$ GJERE MED SPRÅKBLANDing}

Riksem (2018b) analyserer altså språkblanding mellom norsk og engelsk internt i DP i amerikanorsk. Det typiske mønsteret er at ein engelsk substantivstamme blir lånt inn i amerikanorsk og får norsk bøying, t.d. som i (5), henta frå Riksem (2018b, s. 506).

$$
\text { sportsgam[e]-an <= DF.PL.M }
$$

I den strukturelle analysen reknar altså Riksem med at bøyingseigenskapane DEF og NUM (og også GEN) ikkje eksisterer som separate projeksjonar, men at dei er samla under éin funksjonell projeksjon F, som vist ovanfor. I (5) er såleis suffikset -an (dvs. -ane) eksponent for alle desse bøyingseigenskapane. Riksem nemner likevel seinare i artikkelen, i fotnote 29, side 514, at det finst belegg for at eitt og same engelske substantiv kan ha både norsk og engelsk bøying, t.d. (6).

(6) disse pill-s-ane

Ho seier til slutt i fotnoten at dette er svært interessante data, men at artikkelen hennar ikkje gir rom for å analysere dette vidare. Det er nettopp denne typen 
språkblandingsdata eg no skal bruke for å argumentere for at DEF og NUM må analyserast som separate funksjonelle projeksjonar i norsk. ${ }^{1}$

Denne argumentasjonen er basert på Åfarli, Nygård \& Riksem (2020), og i staden for språkblandingsdata frå amerikanorsk, skal eg bruke tilsvarande språkblandingsdata frå moderne norsk (data supplert av Riksem). Dette er data som også er analyserte i Åfarli, Nygård \& Riksem (2020), og nedanfor vil eg derfor tillate meg å berre skissere analysen; ein fullare analyse er gitt i op. cit. Sjå på dataa i (7) og (8).

\section{a. Ser du cardigan-s-ane? \\ b. Cupcake-s-ene}

I begge desse døma er pluralsuffikset engelsk (-s). Det er viktig at det engelske pluralsuffikset både i (7a) og (7b) er av den aktive typen. Dersom vi tar utgangspunkt i t.d. (7a) og den indefinitte pluralforma cardigans (som i mange cardigans), er den tilsvarande singularforma cardigan som i éin cardigan, ikkje cardigans som i *éin cardigans. Dette indikerer at s-suffikset i (7a) er aktivt og uttrykker bøyingseigenskapen plural. Tilsvarande gjeld for cupcake i (7b). Dersom det engelske $s$ suffikset derimot var inaktivt, ville vi også kunne finne det i singularformene. Dette siste gjeld t.d. i éin pins, éin tanks, éin caps. I desse tre døma er det opphavlege engelske pluralsuffikset ikkje lenger aktivt og kan ikkje seiast å uttrykke nokon bøyingseigenskap. ${ }^{2}$

Nedanfor skisserer eg strukturen til cardigansane i (7a).

(8)

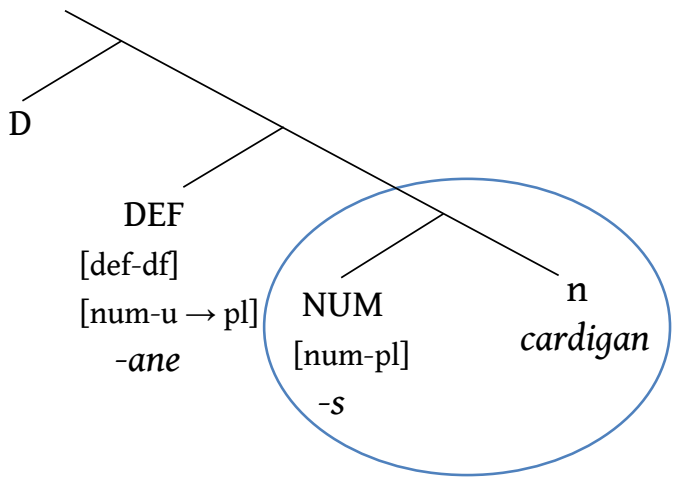

[1] Dette gjer det også rimeleg å sjå på Riksems komprimerte representasjon i (4) som ein forenkla analyse som er tilstrekkeleg for å gjere greie for den typen blandingsdata ho tar for seg i artikkelen sin, men at ein analyse som i tillegg omfatta data som (6), ville ha motivert ein representasjon med separate NUMog DEF-projeksjonar for amerikanorsk i hennar analyse.

[2] Dersom det finst språkbrukarar som aksepterer éin cardigans eller éin cupcakes, noko som ikkje er utenkjeleg, ville det måtte tolkast som at det opphavlege engelske pluralsuffikset heller ikkje lenger var aktivt i desse orda for desse språkbrukarane. 
Dei sentrale stega i derivasjonen er slik: Den delen av strukturen som er inne i sirkelen, blir bygd i den «engelske» delen av den internaliserte grammatikken til språkbrukaren. Dette utgjer ein fase ${ }^{3}$ som blir forsynt med eksponentar frå engelsk, spesielt s-suffikset for num-pl. Den engelske delstrukturen blir så spleisa med ein DEF-kjerne i den «norske» delen av den internaliserte grammatikken til språkbrukaren. Det deltreet som da oppstår, har både ein engelsk og ein norsk komponent. Legg merke til at den norske DEF-kjernen i tillegg til trekket def-df også inneheld eit uvaluert trekk num-u. Dette eksisterer pga. kongruensen mellom NUM og DEF og er standard i norsk DP-struktur. Trekket num-u i DEF blir valuert som $\mathrm{pl}$ av det engelske trekket num-pl i NUM via sonde - målvaluering (probe - goal, sjå t.d. Chomsky 2000, s. 122-124; Grimstad et al. 2018). Trekka def-df og num-pl i DEF blir så realiserte i den «norske» eksponenten -ane under DEF sidan denne realiseringa skjer i den norske delen av strukturen.

Blandingsdata som dei i (6), (7a) og (7b) gir klar empirisk evidens for at NUMog DEF-projeksjonane er separate. Grunngjevinga for dette har å gjere med språkblandingsmekanikken. I bl.a. Grimstad (2018), Riksem (2018a), Grimstad et al. (2018), Riksem et al. (2019), Åfarli, Nygård \& Riksem (2020) blir det rekna med at språkblanding skjer ved at frasestrukturelle einingar frå eitt språk (gjestespråket; engelsk i døma ovanfor) blir integrerte i frasestrukturelle einingar i eit anna språk (vertsspråket, matrisespråket; norsk i døma ovanfor). Dei frasestrukturelle eininga som blir integrerte, kan vere mindre eller større. Ved enkeltord er det ordstammen som blir integrert, men det kan også vere større frasestrukturelle einingar som i (6), (7a) og (7b).

I desse siste døma er det den delen av strukturen som er dominert av NUMprojeksjonen, som blir integrert frå engelsk, medan den delen som består av DEF og oppover, er norsk. Sidan «vekslingspunktet» mellom norsk og engelsk går mellom DEF-projeksjonen og NUM-projeksjonen, må desse to projeksjonane eksistere som separate projeksjonar i strukturen. Dette er det første empiriske argumentet for separate DEF- og NUM-projeksjonar i norsk DP-struktur.

\section{[4] Motivasjon SOM HAR Å GJERE MED INTERAKSJONEN MELLOM POSSES- SIVAR OG SUBSTANTIVBØYING}

Den andre typen empirisk motivasjon for å analysere DEF og NUM som separate projeksjonar i representasjonen av norske DPar har å gjere med korleis pre- og postnominale possessivar interagerer med bøygde former av substantivet.

Det er ei kjent sak at når substantivet er indefinitt, må ein possessiv stå

[3] Her blir omgrepet «fase» brukt ikkje-teknisk. Om den engelske delstrukturen i blandingstilfelle som dette skal reknast som ein fase i teknisk forstand, er eit interessant spørsmål som fortener meir utforsking. T.d. Julien (2005) inneheld nokre tankar om potensielle DP-interne fasar i nordiske språk (utan å ta med språkblandingsfenomen). 
prenominalt, og når substantivet er definitt, må possessiven stå postnominalt (jf. t.d. Taraldsen 1990, Fiva 1987, Julien 2005). Dette er vist i (9a) og (9b).
a. $\quad \min$ bil vs. *bil min
b. bilen min vs. *min bilen

Dersom vi reknar med at definitt-verdien ligg i DEF-kjernen til ein funksjonell DEF-projeksjon, vil dataa i (9a) og (9b) kunne forklarast dersom vi i tillegg reknar med at possessiven er generert mellom DEF og substantivstammen n. Ein slik analyse må likevel kvile på ein avgjerande tilleggspremiss: Substantivstammen blir løfta til DEF berre dersom DEF er «positiv» = df, dvs. berre dersom DEF har ein verdi som svarar til ein morfofonologisk synleg eksponent (på typenivå4). Som kjent er det berre verdien df som er positiv på denne måten; verdien indf er utan unntak «negativ», dvs. aldri korrelert med ein morfofonologisk synleg eksponent.

Analysen av den velforma ordstillinga min bil i (9a) er vist i (10). Legg merke til at eg ikkje har tatt med NUM i trerepresentasjonane av (9a) og (9b) nedanfor. Dette er fordi NUM er irrelevant for argumentasjonen akkurat her. Eg gir analysar av (9a) og (9b) med NUM inkludert i (15) og (16) seinare i denne seksjonen.

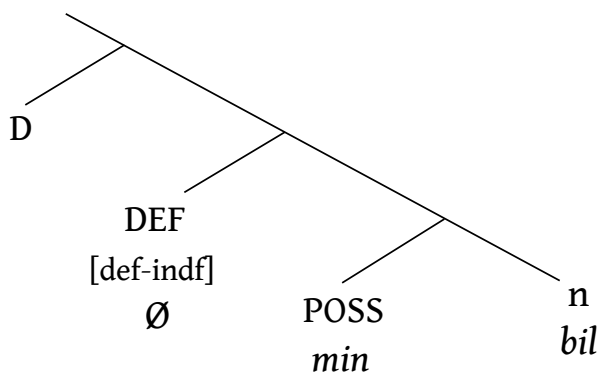

Her kan ikkje substantivstammen bil løftast ${ }^{5}$ til DEF fordi verdien til DEF er indef, altså negativ (fråveret av eksponent er symbolisert med Ø). Dette forklarer også *bil min.

Analysen av den velforma ordstillinga bilen min i (9b) (før løfting av bil til DEF)

[4] Her tenkjer eg på slikt som at nokre slektskapssubstantiv ikkje ser ut til å ha den regelrette definittforma som elles er obligatorisk når possessiven er postnominal, t.d. i far min (takk til Ragnhild Eik, som peika på dette). Eg reknar likevel med at substantivet er definitt her, men at slike slektskapssubstantiv ikkje treng uttrykke dette i ein synleg eksponent i denne konteksten. Legg merke til at i mi dialekt (Halsa, Nordmøre) har far i slike tilfelle sirkumfleks, noko som indikerer at det eigentleg er eller har vore eit suffiks her.

[5] Eg reknar med syntaktisk kjerneflytting internt i DP, nærmare bestemt slik at substantivstammen flyttar oppover til dei funksjonelle kjernane når slik flytting er lisensiert, men ikkje elles. Slik reint syntaktisk kjerneflytting er og har vore mykje diskutert både i DP og i setninga (verbflytting), sjå t.d. Matushansky (2006) eller Roberts (2010). 
er vist i (11).

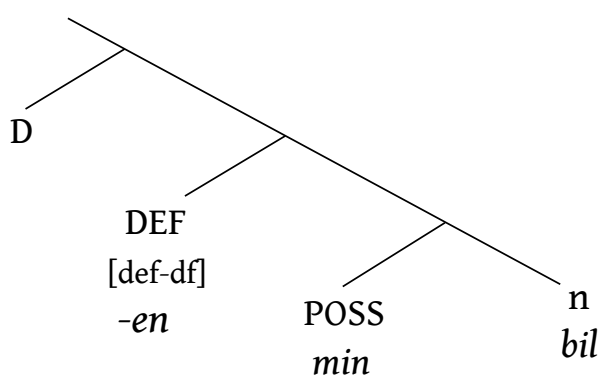

Her er verdien til DEF df, altså positiv, og substantivstammen bil både kan og må løftast til DEF. Dermed er også *min bilen forklart.

Merk at det ikkje er gitt ut frå representasjonane ovanfor om POSS har status som kjerne eller spesifikator. Dersom POSS er kjerne, vil min i POSS i utgangspunktet blokkere kjerneflytting av substantivstammen bil til DEF (pga. relativisert minimalitet eller prinsippet om kortaste flytting, sjå t.d. Rizzi 1990; Boeckx 2006, s. 69-70). Dette er ikkje lenger eit problem dersom POSS er spesifikator (t.d. i nP). Det er alternativt mogeleg at POSS er ein kjerne som i sin natur er så ulik infleksjonskjernar som NUM og DEF at han ikkje er i stand til å blokkere kjerneflytting til slike infleksjonskjernar. Eg tar ikkje stilling til dette problemet i denne artikkelen sidan det ikkje er avgjerande for argumentasjonen min (sjå elles Lødrup 2011 for vidare diskusjon av den frasestrukturelle statusen til possessivpronomen). Det som er viktig, er at POSS ikkje blokkerer kjerneflytting av substantivstammen oppover, uansett kva forklaringa på det måtte vere.

Vi konsentrerer oss no om korleis numerus/NUM interagerer med possessivar. I strukturane for (9a) og (9b) ovanfor er som sagt ikkje NUM vist, men uansett er det i (9a) og (9b) ikkje noko «positivt» NUM-suffiks, berre «negativt», dvs. morfofonologisk uuttrykt singular. Dersom vi ser på tilsvarande døme med uttrykt «positiv» pluralverdi for NUM, altså pl, får vi mønsteret i (12a) og (12b).

a. mine bilar vs. *bilar mine

b. bilane mine vs. ${ }^{*}$ mine bilane

Dette er heilt i tråd med mønsteret i (9a) og (9b) når det gjeld DEF-eigenskapen, men det er interessant at medan possessiven aldri kan stå framfor den positive DEF-verdien verken i (9b) eller (12b), kan possessiven stå framfor den positive NUM-verdien = pl. Dette siste er vist i (12a), og ikkje nok med det, possessiven må stå framfor den positive NUM-verdien pl når substantivet er indefinitt, 
men ikkje når det er definitt som i (12b).

Dette kan forklarast dersom vi reknar med, som ovanfor, at substantivstammen berre flyttar til positive bøyingsverdiar, både når det gjeld df for DEF og pl for NUM, og at slik flytting til positive verdiar også er obligatorisk. Vidare er det avgjerande at possessiven må vere generert nedanfor DEF, men ovanfor NUM (som igjen er generert ovanfor substantivstammen n). Med andre ord må POSS vere generert mellom DEF og NUM, noko som viser at DEF og NUM må vere generert som to separate projeksjonar. Dette er dermed det andre empiriske argumentet for separate DEF- og NUM-projeksjonar i norsk DP-struktur.

Merk at denne analysen av DP-interne possessivar ikkje harmonerer med analysen til Julien (2005) der både pre- og postnominale possessivar blir genererte nedanfor både DEF (hennar $n$ ) og NUM, nærmare bestemt $\mathrm{i}$ hennar spesifikatorposisjon i NP.

Vi ser nærmare på derivasjonane. Min analyse av (12a) (mine bilar vs. *bilar mine) er vist i (13):

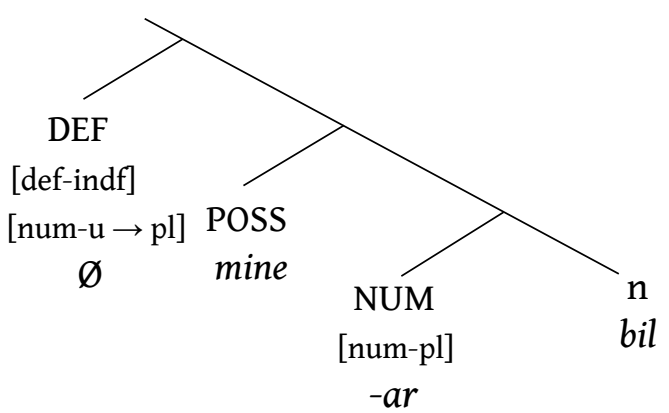

Her må substantivstammen bil flytte til NUM (positiv pl), men kan ikkje flytte til DEF (negativ indf; fråveret av eksponent er symbolisert med Ø), altså er mine bilar ok, medan *bilar mine ikkje er det.

Legg merke til at det er eit kongruenstrekk for numerus (num-u) under DEF som blir valuert som pl frå num-pl under NUM (sjå også (8) og diskusjonen i avsnittet under det). Etter at dette kongruenstrekket er blitt valuert som pl, er dette blitt eit positivt trekk som ein kunne tenkje seg krev vidare flytting av substantivstammen til DEF. Når dette likevel ikkje er mogeleg, er det evidens for at positive bøyingsverdiar berre krev flytting til kjernar der dei er genererte $i$ første omgang, altså at positiv pl berre krev flytting til NUM og at positiv df berre krev flytting til DEF. Derfor vil positiv pl under DEF aldri utløyse flytting, og meir generelt: Positive kongruenstrekk utanfor «heimeprojeksjonane» sine utløyser aldri flytting.

Analysen min av (12b) (bilane mine vs. ${ }^{*}$ mine bilane) er vist i (14). 
(14)

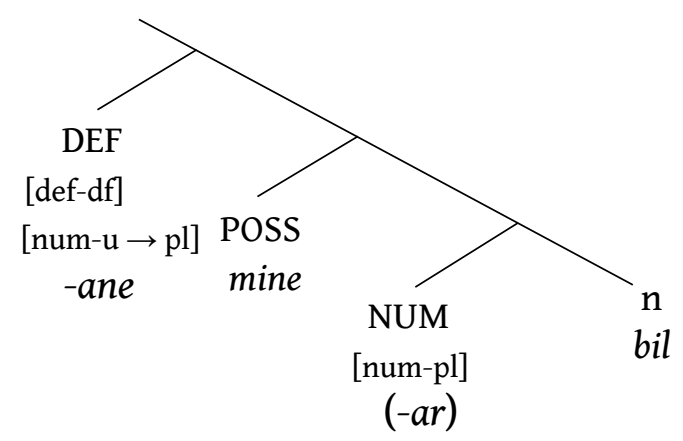

Her har både DEF og NUM positive verdiar (dvs. df og pl), og substantivstammen bil må derfor flytte først til NUM og deretter til DEF. Altså er bilane mine ok, medan *mine bilane ikkje er det.

Legg merke til at eksponenten under NUM står i parentesar. Grunnen til dette er at eg reknar med at eksponentane til bøyingseigenskapane til substantivet ikkje blir realiserte stegvis når vi ikkje har med språkblanding å gjere. Derfor blir eksponenten for num-pl og def-df realisert (som samlemorfen -ane) først under DEF. Dersom bøyingseksponentane vart realiserte stegvis, ville vi vente å få den ikkje velforma forma *bilarane. Dette er forskjellig frå den derivasjonsgangen som skjer ved språkblanding, sjå diskusjonen i samband med (8) i seksjon 3.

Eg skal også vise strukturane til (9a) og (9b) med NUM-projeksjonen inkluderte. Eg startar med strukturen til (9b) (bilen min vs. *min bilen), som er vist $\mathrm{i}$ (15).

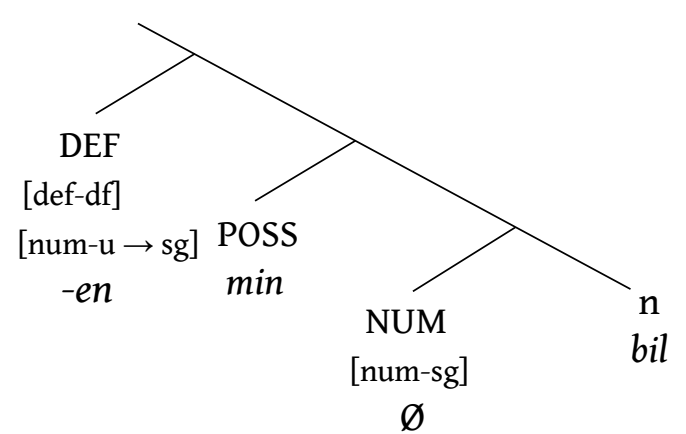

Her tvingar den positive verdien def-df under DEF substantivstammen bil opp til DEF slik at vi får bilen min og ikkje *min bilen. Merk at substantivstammen må flytte innom NUM pga. prinsippet om kortaste flytting (sjå også diskusjonen 
under (11)). Sidan num-sg under NUM er negativ, er det ingenting som tvingar flytting av substantivstammen til NUM, men slik flytting er heller ikkje blokkert i tilfelle som her der denne flyttinga er avgjerande for å oppfylle andre krav (her: obligatorisk flytting av substantivstammen til DEF). Dette er da eit tilfelle av det som metaforisk har vore kalla «opplyst eigeninteresse», sjå Lasnik (1999, s. 127132).

Så har vi strukturen til (9a) (min bil vs. *bil min), som er vist i (16).

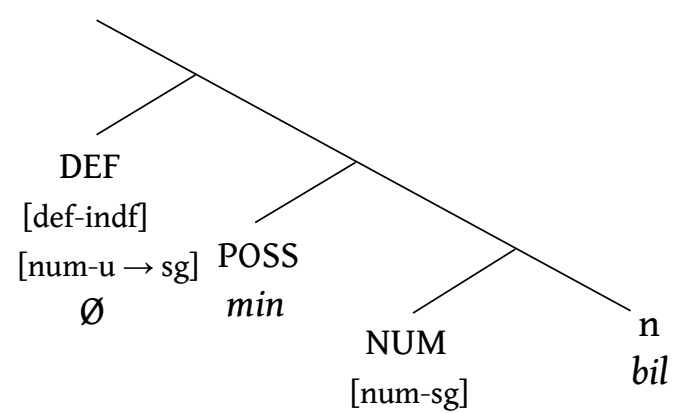

$\varnothing$

Her er det ingen positive trekk verken under NUM eller DEF, og derfor kan ikkje substantivstammen bil flytte. Altså er min bil ok, medan *bil min ikkje er det.

Eg skal oppsummere dei viktigaste poenga i denne seksjonen. Det aller viktigaste er at analysane ovanfor viser at DEF og NUM må eksistere som separate projeksjonar, som altså er det andre empiriske argumentet for separate DEF- og NUM-projeksjonar i norsk DP-struktur. Eit anna poeng, som heng saman med det første poenget, er at analysen som er presentert ovanfor, ikkje harmonerer med analysen i Julien (2005), som seier at både pre- og postnominale possessivar er genererte i spesifikatorposisjonen til (hennar) NP, altså nedanfor både DEF og NUM, som altså står i direkte motstrid til at POSS må vere generert mellom DEF og NUM. ${ }^{6}$ I tillegg til dette er det eit anna viktige poeng med utspring i possessivproblematikken, nemleg at kjerneflytting av substantivstammen til dei funksjonelle bøyingskategoriane NUM og DEF berre kan skje (sett bort frå tilfelle av «opplyst eigeninteresse»), og må skje, dersom verdien til kategorien er positiv, dvs. er korrelert (på typenivå) med ein morfofonologisk uttrykt eksponent. Dette er ein uvanleg og ganske radikal idé med implikasjonar ut over dei fenomena som er diskuterte her, og som (derfor) bør undersøkjast vidare i framtidig

[6] Kva som eigentleg ligg i denne analytiske disharmonien, er uklart all den tid dei to analysane også er ulike på andre måtar. Dermed er det uklart om det er relevante data som den eine analysen kan forklare, men ikkje den andre. Det er ikkje rom for å vurdere dette vidare i denne artikkelen. 
arbeid. $^{7}$

Apropos slikt som bør undersøkjast vidare, vil eg nemne berre eitt problem til, eller kanskje det heller bør karakteriserast som eit større problemkompleks. Det omfattar alt som har å gjere med possessivar i DPar der DPen også inneheld eit attributivt adjektiv. Her er det mange uløyste spørsmål som eg ikkje vil gå nærmare inn på her, sjå Julien (2005) og Olsen (2012) for diskusjonar og analysar som ikkje nødvendigvis er kompatible med mine analysar her.

\section{[4] KONKLUSJON}

I denne artikkelen har eg lagt fram og diskutert to ulike typar empiriske argument for å rekne med at DEF og NUM eksisterer som separate kjernar/projeksjonar i strukturen til DP i norsk. Det første argumentet har å gjere med språkblanding mellom norsk og engelsk både i amerikanorsk og elles. Det andre argumentet har å gjere med interaksjonen mellom pre- og postnominale possessivar og bøyingsmorfologien knytt til substantivet i DPen. Analysane i begge tilfella viser klar evidens for at DEF og NUM er separate kjernar/projeksjonar.

\section{TAKK}

Takk for gode og nyttige kommentarar frå to anonyme fagfellar og frå deltakarane ved syntaksseminaret «Skogselskapet» ved NTNU der dette stoffet vart presentert hausten 2020. Eg vil spesielt takke for skogselskap-innspela frå Yvonne van Baal, Ragnhild Eik, Ingrid Marie Heiene, Dave Kush, Terje Lohndal, Andrew Weir og Chris Wilder. Takk også til det internasjonale forskingsprosjektet MultiGender ved Senter for grunnforsking, Det Norske Videnskaps-Akademi i Oslo, der nokre av idéane i denne artikkelen vart utvikla i løpet av opphalda mine der det akademiske året 2019-2020.

\section{REFERANSER}

Abney, Steven P. 1987. The English noun phrase in its sentential aspect. Doktoravhandling, MIT.

Bobaljik, Jonathan D. \& Höskuldur Thraínsson. 1998. Two heads aren't always better than one. Syntax 1.37-71.

Boeckx, Cedric. 2006. Linguistic Minimalism: Origins, concepts, methods, and aims. Oxford: Oxford University Press.

[7] I samband med dette vil det t.d. vere interessant å undersøkje ein hypotese om at negativ verdi faktisk kan bety at kategorien/projeksjonen ikkje finst. Det er ikkje rom for å diskutere den teoretiske statusen til morfosyntaktiske trekk vidare i denne artikkelen. Sjå bl.a. Julien (2005), Zeijlstra (2008), Kinn (2020) for interessante innspel til ein vidare diskusjon. 
Chomsky, Noam. 2000. Minimalist inquiries: The framework. I Roger Martin, David Michaels \& Juan Uriagereka (red.) Step by step: Essays on Minimalist syntax in honor of Howard Lasnik, s. 89-155. Cambridge, Mass.: The MIT Press.

Embick, David \& Rolf Noyer. 2007. Distributed Morphology and the syntax - morphology interface. I Gillian Ramchand \& Charles Reiss (red.) The Oxford handbook of linguistic interfaces, s. 289-324. Oxford: Oxford University Press.

Fiva, Toril. 1987. Possessor chains in Norwegian. Oslo: Novus.

Grimstad, Maren Berg. 2018. English-origin verbs in American Norwegian. Doktoravhandling, NTNU.

Grimstad, Maren Berg; Riksem, Brita Ramsevik; Lohndal, Terje; Åfarli, Tor Anders. 2018. Lexicalist vs. exoskeletal approaches to language mixing. The Linguistic Review 35. 187-218.

Hellan, Lars, 1986. The headedness of NPs in Norwegian. I Peter Muysken \& Henk van Riemsdijk (red.) Features and Projections, s. 89-122. Dordrecht: Foris.

Julien, Marit. 2005. Nominal phrases from a Scandinavian perspective. Amsterdam: John Benjamins.

Kinn, Kari. 2020. Stability and attrition in American Norwegian nominals: A view from predicate nouns. Journal of Comparative Germanic Linguistics 23. 3-38.

Lasnik, Howard. 1999. Minimalist analysis. Malden: Blackwell.

Lohndal, Terje. 2019. The exoskeletal model. Upublisert ms, NTNU. [Blir publisert i The Cambridge Handbook of Distributed Morphology, redigert av Artemis Alexiadou, Ruth Kramer, Alec Marantz \& Isabel Oltra-Massuet.]

Lødrup, Helge. 2011. Norwegian possessive pronouns: Phrases, words or suffixes? I Miriam Butt \& Tracy Holloway King (red.) Proceedings of the LFG11 Conference, s. 339-359. Stanford: CSLI Publications.

Matushansky, Ora. 2006. Head Movement in Linguistic Theory. Linguistic Inquiry 37. 69-109.

Olsen, Alma. 2012. En syntaktisk analyse av DP-interne possessiver i norsk. Masteroppgåve, NTNU.

Pollock, Jean-Yves. 1989. Verb movement, Universal Grammar, and the structure of VP. Linguistic Inquiry 20. 365-424. 
Riksem, Brita Ramsevik. 2018a. Language mixing in American Norwegian noun phrases: An exoskeletal analysis of synchronic and diachronic patterns. Doktoravhandling, NTNU.

Riksem, Brita Ramsevik. 2018b. Language mixing in American Norwegian noun phrases. Journal of Language Contact 11. 481-524. [Også trykt som “Article 2" i Riksem (2018a).]

Riksem, Brita Ramsevik; Grimstad, Maren Berg; Lohndal, Terje; Åfarli, Tor Anders. 2019. Language mixing within verbs and nouns in American Norwegian. Journal of Comparative Germanic Linguistics 22. 189-209.

Rizzi, Luigi. 1990. Relativized Minimality. Cambridge, Mass.: The MIT Press.

Roberts, Ian. 2010. Agreement and Head Movement: Clitics, Incorporation, and Defictive Goals. Cambridge, Mass.: The MIT Press.

Taraldsen, Knut Tarald. 1990. D-projections and N-projections in Norwegian. I Joan Mascaró \& Marina Nespor (red.) Grammar in progress: GLOW essays for Henk van Riemsdijk, s. 419-431. Dordrecht: Foris.

Zeijlstra, Hedde. 2008. On the syntactic flexibility of formal features. I Theresa Biberauer (red.) The Limits of Syntactic Variation, s. 143-174. Amsterdam: John Benjamins.

Åfarli, Tor A., Mari Nygård \& Brita Ramsevik Riksem. 2020. Gender 'translation' and distributed gender: Evidence from the Norwegian DP and language mixing. Upublisert ms, NTNU.

KONTAKT

Tor A. Åfarli,

NTNU, Trondheim

tor.aafarli@ntnu.no 